\title{
POLITYKA ETNICZNA PAŃSTWA UKRAIŃSKIEGO W KONTEKŚCIE JEGO KIERUNKU PROEUROPEJSKIEGO
}

\author{
Ethnic Policy of the Ukrainian State \\ in the Context of its Pro-European Direction
}

After Ukraine gained independence, the ethnic policy of this state has contributed to the transformation of the concept of the Ukrainian nation from ethnic into civic one. For this purpose, a package of legal acts modelled on international law has been adopted. The management of ethnic policy in Ukraine has saved the public from high levels of xenophobia and ethnic conflict. At the same time, the process of national integration is slowing down because some ethnic minorities prefer their own ethnic identity to the national civic one.

Keywords: Ukrainian state, national policy, minority rights, multi-ethnic nation, ethnical self-identification priorities.

Potwierdzeniem gotowości i zdolności Ukrainy do spełnienia europejskich kryteriów cywilizacyjnych powinny być przemiany demokratyczne w różnych sferach społecznych. W sferze etnopolitycznej wymóg demokratyzacji oznacza przede wszystkim dostosowanie prawa krajowego regulującego tę sferę do zasad prawa unijnego oraz wdrożenie tych zasad do praktyki polityki etnicznej i narodowej państwa.

Uzyskanie przez Ukrainę niepodległości było ucieleśnieniem prawa ukraińskiego narodu politycznego do samostanowienia. W 1991 roku etniczni Ukraińcy stanowili prawie trzy czwarte całej populacji 
państwa, czyli 72,7 proc., podczas gdy w roku 2001 - już 77,8 proc. Jednocześnie demograficzna dominacja etnosu tytularnego nie pokrywała się i do dziś nie pokrywa $z$ odpowiednią dominacją w życiu społecznym pod katem rozprzestrzenienia w społeczeństwie języka i kultury ukraińskiej oraz innych cech tożsamości etnicznej, co jest następstwem długotrwałej rusyfikacji. Taka sytuacja przetrwała do dziś.

Równolegle w społeczeństwie ukraińskim zaczęła umacniać się koncepcja wieloetnicznego narodu ludzi zjednoczonych przez wspólne obywatelstwo. Na mocy dekretu Prezydenta Ukrainy $z$ dnia 31 grudnia 1991 roku O trybie zmiany narodowości przez obywateli Ukrainy ${ }^{1}$ obywatele otrzymali prawo do swobodnej zmiany swojej przynależności etnicznej. W dalszej kolejności otrzymali prawo do podania podczas spisów ludności swojej przynależności etnicznej bez względu na wpis w dowodzie osobistym lub przynależności etniczne swoich rodziców.

Kwestia ewolucji narodu ukraińskiego od wspólnoty etnicznej do obywatelskiej zasługuje na uwagę pod tym względem, że pierwszy model tworzenia narodu $z$ reguły kojarzy się $z$ etnokracja, dominacja etnosu tytularnego i jego dażeniem do zasymilowania innych, drugi zaś - ze stworzeniem warunków do umocnienia wielokulturowości, zapewnienia równości wszystkich etnicznych segmentów społeczeństwa oraz zagwarantowania praw mniejszości narodowych.

Rozwój ukraińskiego ustawodawstwa w zakresie sfery etnopolitycznej odbywał się na zasadach charakterystycznych dla drugiego modelu. Jeszcze na rok przed upadkiem Związku Radzieckiego, w dniu 16 lipca 1990 roku Rada Najwyższa USRR przyjęła Deklarację o suwerenności państwowej Ukrainy, w której obok prawa ukraińskiego narodu etnicznego do samostanowienia zagwarantowano prawo wszystkich narodowości do ich rozwoju narodowo-kulturowego ${ }^{2}$. Podczas uchwalenia w dniu 24 sierpnia 1991 roku Aktu proklamowania niepodległości Ukrainy (w którym ukraiński naród etniczny nie figuruje jako podmiot samostanowienia) Prezydium Rady Najwyższej wystosowało Orędzie do obywateli Ukrainy wszystkich narodowości, w którym zagwarantowano równe prawa wszystkim obywatelom i swobodny rozwój wszystkich języków i kultur narodowych ${ }^{3}$.

W 1991 roku ustawowo wprowadzono tzw. opcję zerowa - prawo do otrzymania ukraińskiego obywatelstwa przez wszystkie osoby,

1 Ukaz Prezidenta Ukraïni „Pro porâdok zmìni gromadânami Ukraïni nacìonal'nostì”, http: / / search.ligazakon.ua/1_doc2.nsf/link1/U0024U0.html [dostęp: 4 lipca 2020].

Deklaraciâ pro deržavnij suverenitet Ukraïni, „Radâns'ka Ukraïna”, 17 VII 1990.

3 Akt progološennâ nezaležnostì Ukraïni, „Radâns'ka Ukraïna”, 31 VIII 1991. 
które na stałe mieszkały w kraju, bez względu na ich przynależność etniczna. W dniu 1 listopada 1991 roku Rada Najwyższa przyjęła Deklaracje praw narodowości Ukrainy, która gwarantowała równość wobec prawa dla etnosu tytularnego i mniejszości narodowych, prawo mniejszości do tworzenia narodowych jednostek podziału administracyjnego na obszarach tradycyjnego osiedlenia i do swobodnego posługiwania się językami narodowymi we wszystkich sferach życia publicznego. Państwo gwarantowało każdej narodowości swobodne wyrażenie swej samoistności, prawo do edukacji, zrzeszania się, swobodnego utrzymywania więzi $z$ historyczną ojczyzną, a także zobowiązywało się do ochrony zabytków historii i kultury wszystkich narodów i grup narodowych ${ }^{4}$.

Podstawowym aktem prawnym $\mathrm{w}$ sferze polityki narodowej i etnicznej państwa ukraińskiego stała się Ustawa o mniejszościach narodowych na Ukrainie z $1992 \mathrm{roku}^{5}$. Ustawa ta de facto określiła podstawowe zasady tej polityki: nierozerwalność praw człowieka i praw wspólnoty etnicznej, równość politycznych, społecznych, ekonomicznych i kulturalnych praw obywateli republiki bez względu na ich pochodzenie narodowe, prawo do ochrony przez państwo, jedność praw osób należących do mniejszości narodowych i ich obowiązów obywatelskich, prawny zakaz i sadowe karanie za jakiekolwiek pośrednie i bezpośrednie ograniczanie praw i wolności ze względu na przynależność etniczną.

Do praw, które państwo zobowiązało się gwarantować mniejszościom narodowym, należą: prawo do autonomii narodowo-kulturowej, prawo do ochrony zabytków historii i kultury, prawo do przygotowania kadr pedagogicznych, kulturalno-oświatowych i innych, w tym za granica, prawo do posługiwania się językiem mniejszości narodowej obok języka państwowego w pracy przedsiębiorstw, instytucji i organizacji usytuowanych na obszarach, gdzie liczebnie dominuja przedstawiciele tej mniejszości, czynne i bierne prawa wyborcze przedstawicieli mniejszości narodowych oraz ich prawa do zajmowania różnych stanowisk w organach władzy i administracji publicznej, prawo do zachowania środowiska życia mniejszości, prawo do powrotu przedstawicieli mniejszości na terytorium Ukrainy oraz prawo do swobodnego wyboru przez jednostkę swej przynależności etnicznej.

\footnotetext{
4 Deklaraciâ prav nacional'nostej Ukraïni, w: Prava lûdini v Ukraïnì, vip. 21, Kiïv 1998, s. $446-447$.

5 Zakon Ukraïni „Pro nacional'nì menšini v Ukraïni”, w: Prava lûdini v Ukrä̈ni, vip. 21, Kiïv 1998, s. 442-445.
} 
Ustawa o mniejszościach narodowych na Ukrainie została przyjęta jednocześnie $z$ zadeklarowaniem przez Ukrainę jej zamiaru integracji ze Wspólnota Europejska oraz dostosowania się do norm i standardów prawnych rozwiniętego świata. Demonstracja takiej gotowości stał się osobny artykuł ustawy o nadrzędnym charakterze przepisów umów międzynarodowych ratyfikowanych przez Ukrainę.

Ważnym krokiem w tym kierunku stało się wstąpienie Ukrainy do Rady Europy (RE) w 1995 roku i jej dołaczenie do Konwencji o ochronie praw człowieka i podstawowych wolności z 1950 roku, a także ratyfikacja protokołów dodatkowych do tej konwencji. Komisja Zagadnień Prawnych i Praw Człowieka Zgromadzenia Parlamentarnego Rady Europy stwierdziła wtedy, że prawo ukraińskie nie uznaje idei państwa etnicznego, a ukraińska ustawa o mniejszościach narodowych może być uważana za wzorową wśród odpowiednich ustaw państw Europy Środkowej i Wschodniej jako dobrze dostosowana do norm prawa europejskiego ${ }^{6}$.

W dniu 28 czerwca 1996 roku została przyjęta Konstytucja Ukrainy. Ustawa zasadnicza nałożyła na państwo szereg obowiązków w zakresie rozwoju wspólnot etnicznych Ukrainy. Do obowiązków konstytucyjnych państwa należą m.in.:

- wsparcie obywateli w nauce języków obcych umożliwiających porozumiewanie się między narodami (art. 10);

- poparcie dla konsolidacji i rozwoju narodu ukraińskiego, jego historycznej świadomości, tradycji i kultury, a także dla rozwoju etnicznego, kulturowego, językowego i religijnego tożsamości wszystkich rdzennych ludów i mniejszości narodowych Ukrainy (art. 11);

- zapewnienie dostępności bezpłatnego kształcenia na wszystkich poziomach w państwowych i komunalnych instytucjach oświatowych (art. 53);

- ochrona zabytków historycznych oraz innych obiektów o wartości kulturowej (art. 54) i inne ${ }^{7}$.

Wiarygodność zamiaru integrowania się z Europa niepodległa Ukraina potwierdziła poprzez ratyfikację podstawowych umów międzynarodowych dotyczących ochrony mniejszości narodowych, ich kultur i języków, m.in. Międzynarodowego Paktu Praw Obywatelskich i Politycznych, Międzynarodowego Paktu Praw Gospodarczych, Społecznych $i$ Kulturalnych, Konwencji $w$ sprawie zapobiegania $i$ karania

\footnotetext{
6 Prava lûdini, w: İnformacìjnij bûleten' Harkìvs'koï pravozahisnoï grupi: Specvipusk, 5 XI 1995, s. 5.

7 Zob. O.N. Bikov, Konstitucìno-pravovij status nacional'nih menšin v Ukraïnì, Kiïv 2001 , s. 67.
} 
zbrodni ludobójstwa, Konwencji o ochronie praw człowieka i podstawowych wolności (1997), Konwencji ramowej Rady Europy o ochronie mniejszości narodowych (1997), Europejskiej karty języków regionalnych lub mniejszościowych (2003) i in.

Niemniej jednak, demonstrując swoja proeuropejskość, Ukraina zbyt mechanicznie przenosiła przepisy umów międzynarodowych na grunt krajowy, co komplikowało prawne uzasadnienie działań w zakresie wsparcia wspólnot etnicznych, gdy go potrzebowały. Tak więc na przykład przepis art. 24 Konstytucji Ukrainy o niedopuszczalności stosowania przywilejów lub ograniczeń $z$ powodu pochodzenia narodowego (etnicznego) bez wzmianki o możliwości zrobienia wyjątku w postaci dodatkowego wsparcia dla tych lub innych wspólnot, jak to ma miejsce w praktyce państw zachodnich, stało się argumentem przeciwników ukrainizacji, którzy określali działania różnych rządów w zakresie rozszerzenia sfery wykorzystania języka ukraińskiego mianem dyskryminacji użytkowników innych języków. Szczególnie dobitna ilustracja niebezpieczeństwa mechanicznego powielenia norm prawa europejskiego przez ukraińskiego ustawodawcę była ustawa o ratyfikacji Europejskiej karty języków regionalnych lub mniejszościowych. Podczas gdy w Europie konwencja ta jest stosowana tylko w odniesieniu do języków rzeczywiście zagrożonych zniknięciem, w ukraińskiej ustawie do wykazu języków objętych ochroną przez Kartę dodano język rosyjski, którym posługuje się połowa ludności kraju, mimo że udział procentowy etnicznych Rosjan według spisu ludności z 2001 roku wynosi jedynie 17 proc.

Dobitna ilustracja prawdopodobieństwa powstania problemów w wyniku bezrefleksyjnego zapożyczenia norm prawa międzynarodowego przewidzianych dla sytuacji, które nie maja analogii w realiach ukraińskich, stał się m.in. problem statusu narodu krymskotatarskiego. Politycznie aktywna część Tatarów krymskich podniosła przed władzami kwestię uznania ich za naród rdzenny (indigenous people) $\mathrm{w}$ tym znaczeniu, w jakim to pojęcie jest definiowane $\mathrm{w}$ odpowiedniej Konwencji Międzynarodowej Organizacji Pracy z 1989 roku. Argumenty przywódców Tatarów krymskich opierały się na obecności terminu „narody rdzenne” w Konstytucji Ukrainy. Władze oraz środowiska eksperckie musiały dołożyć wielkich starań, by przekonać społeczeństwo, że „narody rdzenne” w Konstytucji Ukrainy i indigenous people w Konwencji MOP nie sa tożsamymi podmiotami: termin korinnyj 'rdzenny' w tradycji języka ukraińskiego jest synonimem terminu awtochtonnyj 'autochtoniczny'. 
Dostosowujac ustawodawstwo krajowe do prawa europejskiego, Ukraina powinna uwzględniać także to, że jego nadmierna liberalizacja, bez uwzględnienia specyfiki sytuacji w kraju, może przynieść skutki odwrotne do konsensusu, jak to demonstruje dzisiejsze oburzenie narodowych większości w wielu państwach europejskich, gdzie mniejszości imigranckie zaczęły się domagać zaspokojenia swoich potrzeb językowych, kulturowych i religijnych w takiej skali, że to zaczęło być odbierane jako zagrożenie dla tożsamości etnosów tytularnych.

Liberalny charakter ukraińskiej ustawy o obywatelstwie wraz z ustawą o mniejszościach narodowych daje możliwość grupom tzw. nietradycyjnych, czyli niedawno przybyłych imigrantów domagać się dla siebie wszystkich praw gwarantowanych mniejszościom narodowym przez prawo. W przypadku zachowania w ramach prawnych państwa zasady uniwersalizacji pojęcia „mniejszość narodowa” i automatycznego rozszerzenia jego zakresu także o nowo powstałe naturalizowane grupy „nietradycyjnych” imigrantów stosunki etnopolityczne na Ukrainie moga podążyć nie droga harmonizacji, tylko droga narastania napięcia międzyetnicznego na skutek gwałtownego powiększenia się podmiotów etnopolitycznych angażujących się w walkę o zasoby społeczne i polityczne. Może to prowadzić do rozczarowania społeczeństwa liberalizacja jako naczelną zasada ustroju demokratycznego wraz $z$ odpowiednim zwracaniem się w stronę bardziej twardej formy zarzadzania procesami etnopolitycznymi.

Zasady prawa europejskiego $\mathrm{w}$ sferze polityki etnicznej mogłyby być wdrożone w prawie ukraińskim dużo bardziej kompleksowo i całościowo na mocy dokumentu ustanawiającego zasady polityki etnicznej i narodowej państwa. W Radzie Najwyższej Ukrainy zaproponowano kilka wariantów Koncepcji państwowej polityki etnicznej i narodowej, żaden $z$ nich jednak nie doszedł do etapu rozpatrzenia, co hamuje proces doskonalenia ram prawnych i usprawnienia realizacji polityki etnicznej przez państwo.

Niedokończony proces tworzenia ram prawnych dla polityki etnicznej i narodowej państwa istotnie przeszkadza w dokonaniu jednoznacznego i ostatecznego wyboru modelu etnopolitycznego dla państwa, który ma opierać się albo na koncepcji narodu monoetnicznego, w której etniczni Ukraińcy zajmuja paternalistyczna pozycję wobec mniejszości narodowych, albo na koncepcji narodu wieloetnicznego żyjącego według zasad konsocjonalizmu.

Obserwowane tendencje ewolucji etnospołecznej w społeczeństwie ukraińskim wspierają oba modele. $Z$ jednej strony potęguje się pro- 
ces kształtowania się narodu wieloetnicznego, z drugiej zaś liberalizacja sfery etnopolitycznej po upadku reżimu totalitarnego sprzyja pluralizmowi etnokulturowemu społeczeństwa, umocnieniu się w świadomości przedstawicieli wspólnot etnicznych ich odrębności od „innych”. Odrodzenie etniczne wzmocniło poczucie samozachowania i dało nowe życie jego tradycyjnym mechanizmom, $z$ których za najbardziej skuteczny uważana jest endogamia - zawieranie małżeństw wewnątrz własnej wspólnoty etnicznej. Tak więc odsetek ludzi będacych w małżeństwach monoetnicznych w ciagu lat 1992-2017 wzrós1 od 53 do 70 proc. $^{8}$

Działania niektórych mniejszości daja podstawy, by watpić w nadrzędność ich tożsamości obywatelskiej wobec tożsamości etnicznej. Innymi słowy, istnieją wątpliwości co do ich chęci integrowania się $z$ narodem ukraińskim, również $\mathrm{w}$ jego wariancie wieloetnicznym. Tak więc na przykład obserwowana jest masowa pozytywna reakcja Rumunów, Węgrów, Polaków na apele ich ojczyzn historycznych, by otrzymywać specjalny status stymulujący ich odrębność wobec kraju zamieszkania. Przykładowo według niektórych obliczeń w ostatnich latach liczba obywateli Ukrainy posiadających węgierski paszport miała wynosić 94 tys. osób, rumuński paszport miało od 10 do 50 tys. mieszkańców Bukowiny, rosyjski - według różnych szacunków - od 140 do 350 tys. osób, Kartę Polaka - ponad 60 tys. osób9. Opór tzw. rosyjskiego świata wobec procesu ukrainizacji stał się jednym $z$ mechanizmów przejścia części ludności Donbasu i Krymu na stronę agresora. Lojalność etniczna okazała się dla tej ludności ważniejsza niż demokracja oraz prawa i wolności człowieka.

Opracowane zasady prawne polityki etnicznej i narodowej państwa pełnia rolę regulatora w zarządzaniu etnopolitycznym. Na centralnym i lokalnym poziomie władzy państwowej i administracji publicznej zarządzanie etnopolityczne prowadzone jest przez strukturę instytucjonalną, której powierzono współpracę $z$ organizacjami pozarządowymi mniejszości. W ciagu dłuższego czasu istniała centralna

\footnotetext{
Ukraïnske suspil'stvo. Monitoring social'nih zmìn, vip. 4 (18), Kiïv 2017, s. 596.

9 Nazvali vražaûču kìl'kìst' ugors'kih pasportìv na Zakarpattì, Gazeta.ua, 21 IV 2018, https://gazeta.ua/articles/life/_nazvali-vrazhayuchu-kilkist-ugorskih-pasportiv-nazakarpatti/833134 [dostęp: 6 lipca 2020]; Čotiri kraïni rozdaût' ukraïncâm svoï pasporti, Tižden'.ua, 20 VIII 2012, http://m.tyzhden.ua/post/58219 [dostęp: 6 lipca 2020]; Podvìjne gromadânstvo, zaboronene ukraïns'koû Konstituciêû, procvitaê na Bukovini, TSN.ua, 13 VII 2007, <https://tsn.ua/ukrayina/podviine-gromadyanstvo-v-ukrayini.htm>1 [dostęp: 6 lipca 2020]; "Kartu polâka” otrimali majže 60 tisâč gromadân Ukraïni, İnformacijne agentstvo UNİAN, 9 II 2015, https://www.unian.ua/society/1041882-kartu-polyaka-otrimali-mayje-60-tisyach-gromadyan-ukrajini.html [dostęp: 6 lipca 2020].
} 
instytucja (najpierw ministerstwo, a następnie komitet państwowy) odpowiedzialna za politykę etniczna i narodowa państwa, której funkcje przekazano obecnie Ministerstwu Kultury. Ponadto w strukturach administracji obwodowych funkcjonuja specjalistyczne jednostki lub pracuja specjalnie zatrudnieni fachowcy odpowiedzialni za pracę z mniejszościami narodowymi.

Jednocześnie brak koncepcyjnie przyjętych i prawnie uregulowanych zasad polityki państwowej w sferze etnopolitycznej znajduje swój wyraz w licznych problemach powstajacych w państwowym zarządzaniu etnopolitycznym. Przede wszystkim na skutek jednostronności sfery przedmiotowej polityki etnicznej - jej skupienia się wyłącznie na mniejszościach narodowych - w zakresie państwowego zarządzania etnopolitycznego nie były prowadzone w szerszej skali działania skierowane na zachowanie i wzmocnienie tożsamości większości narodowej oraz utrwalenie jej statusu jako etnicznego rdzenia społeczeństwa. Jednocześnie kierowanie jednostronnej uwagi na mniejszości narodowe ma swoje ograniczenia - uwaga ta skupia się głównie na ich odrodzeniu kulturowym, które przejawia się poprzez festiwale, konkursy, koncerty, wydarzenia literackie i artystyczne itd. Organizacja takich wydarzeń skierowana jest na wspieranie odrodzenia języka i kultury mniejszości. Takie priorytety $\mathrm{w}$ zarządzaniu powoduja jednak zastój w codziennej pracy w zakresie zachęcania przedstawicieli mniejszości do poznania historii, tradycji, trybu życia swojej wspólnoty. Przeciwna tendencją jest niechęć niektórych mniejszości do dostosowania się do ukraińskiego środowiska językowo-kulturowego, ich pragnienie, aby dobrowolnie pozostać w gettoizolowanym stanie. Ilustracja tego jest opór stawiany przez wielu Węgrów temu, aby ich dzieci kształciły się w języku ukraińskim.

Praktyka pokazała, że priorytet tożsamości etnicznej nad obywatelską utrudnił pełną integrację społeczna i zawodową niektórych mniejszości w życiu społecznym państwa. Jedna $z$ głównych przeszkod jest słaba znajomość języka ukraińskiego jako języka państwowego przez osoby wywodzące się $z$ mniejszości. W celu przezwyciężenia tej przeszkody w 2017 roku na Ukrainie przyjęto ustawę o edukacji ${ }^{10}$, na mocy której we wszystkich instytucjach oświatowych wprowadzono nauczanie w języku państwowym przy jednoczesnym zagwarantowaniu osobom należącym do mniejszości narodowych prawa do nauki w językach odpowiednich mniejszości narodowych obok języka pań-

10 Zakon Ukraïni „Pro osvitu”, https://zakon.rada.gov.ua/laws/show/2145-19\#Text [dostęp: 6 lipca 2020]. 
stwowego w samorządowych instytucjach oświatowych. Artykuł ten wywołał negatywne reakcje ze strony niektórych mniejszości narodowych. Spotkał się ze szczególnie wrogim nastawieniem ze strony działaczy mniejszości węgierskiej zamieszkałej na Zakarpaciu i posługującej się w miejscach zwartego zamieszkania wyłącznie językiem węgierskim. Działaczy mniejszości węgierskiej poparł rząd Węgier, zainteresowany tym, aby dla młodych pokoleń ukraińskich Węgrów to ich ojczyzna historyczna - a nie państwo, którego sa obywatelami była jedynym miejscem ich spełnienia społecznego.

Permanentnie kryzysowy stan ukraińskiej gospodarki w ciagu całego okresu niepodległości istotnie ograniczał rząd w asygnowaniu środków na rozwiązywanie problemów społecznych repatriantów. Mimo to państwo ukraińskie w miarę możliwości okazywało pomoc repatriantom poprzez zapewnienie im pracy, działek gruntowych, mieszkań lub materiałów budowlanych, a także dostarczanie wody i gazu w miejsca ich zwartego zamieszkania. Zaspokajano także potrzeby duchowe byłych przesiedleńców poprzez odnowienie zabytków historii i kultury, przywrócenie historycznych nazw miejscowości, wprowadzenie języka narodowego do systemu edukacji i do przestrzeni informacyjnej.

Istotnie mniejszy odsetek osób ukraińskojęzycznych w porównaniu $z$ odsetkiem etnicznych Ukraińców wymagał zastosowania w zarządzaniu etnopolitycznym zasady dodatkowego wsparcia dla języka ukraińskiego. Najbardziej skuteczna forma tego wsparcia powinno być zagwarantowanie językowi ukraińskiemu statusu jedynego języka państwowego i wdrożenie specjalnych programów na rzecz jego upowszechnienia we wszystkich sferach społecznych.

Podczas gdy w większości państw europejskich języki większości narodowych w praktyce zajęły dominujące pozycje, na Ukrainie wciąż mamy do czynienia $z$ sytuacja, gdy w życiu codziennym dominuje język jednej z mniejszości narodowych. Do takiego stwierdzenia prowadzi przede wszystkim stan przestrzeni informacyjnej Ukrainy. Dla przykładu, według danych za lata 2014 i 2016 udział gazet wydawanych w języku ukraińskim wynosił odpowiednio 29,5 proc. i 34,1 proc. ogólnego rynku prasy. Udział czasopism i innych periodyków w języku ukraińskim wynosił odpowiednio 9,9 proc. i 24,4 proc. ${ }^{11}$

${ }_{11}$ Stan ukraïns'koï movi. Ŝròicnij monitoring: Rosijs'ka domìnuê $v$ medìa ta sferì poslug, ukraïns'ka - $v$ osvitì $j$ kinoprokatì, Texty.org.ua, 8 XI 2016, https://texty.org.ua/articles/72173/Stan_ukrajinskoji_movy_Shhorichnyj_monitoryng_Rosijska_dominuje-72173/ [dostęp: 6 lipca 2020]. 
Faktycznie na Ukrainie cały czas podejmowano próby utrwalenia niedemokratycznego typu polityki językowej państwa ${ }^{12}$, który charakteryzuje to, że rządzące elity dawnej kolonii przyznają status języka „narodowego" językowi dawnej metropolii, którym zwykły się posługiwać i który jest językiem ich grupy społecznej. Warto odnotować, że zdecydowane zwiększenie kwot na wykorzystanie języka ukraińskiego w programach telewizyjnych i radiowych nastapiło tylko w 2016 roku.

Zgodnie $z$ europejskimi zasadami społeczeństwa obywatelskiego władze państwowe cały czas demonstrowały gotowość do dialogu $z$ organizacjami pozarządowymi mniejszości narodowych. Na Ukrainie działa ponad 1,2 tys. stowarzyszeń mniejszości narodowych, w tym ponad 30 o zasięgu ogólnokrajowym.

Ze strony państwa cały czas podejmowano kroki wynikające z zobowiązań przewidzianych przez europejskie akty prawne, których sygnatariuszem jest Ukraina. Tuż po uzyskaniu niepodległości na mocy uchwały Gabinetu Ministrów został przyjęty kurs na stworzenie redakcji specjalizujących się w publikacji literatury w językach mniejszości narodowych. W 1995 roku Gabinet Ministrów uchwalił Koncepcję rozwoju kultur mniejszości narodowych, która przewiduje wsparcie państwa dla kształcenia kadr dla kultur narodowych, organizację działalności kulturalno-wychowawczej, twórczości artystycznej, tworzenie i pomoc dla mediów. Dzięki subsydiom rządowym wydawanych jest szereg gazet $\mathrm{w}$ językach mniejszości narodowych będacych dodatkami do dziennika „Hołos Ukrajiny”, w tym „Dziennik Kijowski” w języku polskim ${ }^{13}$.

Państwo ukraińskie podejmowało także działania skierowane na zapobieganie nienawiści na tle etnicznym. Ogólną atmosferę stosunków międzyetnicznych na Ukrainie na ogół cechowała stabilność dość wysokiego poziomu tolerancji. Systematycznie wzrastał i w 2016 roku osiagnął poziom 90 proc. udział osób, które nie spotykały się z przejawami dyskryminacji etnicznych Ukraińców, Rosjan lub Żydów. Niemniej jednak w 2017 roku 41 proc. osób uważało, że konflikty między niektórymi grupami etnicznymi na Ukrainie sa możliwe, podczas gdy przeciwną opinię wyraziło mniej osób -32 proc. $^{14}$

12 Zob. na ten temat: I.V. Popesku, Âzykovaâ politika i proekty zakona o âzykah: ih sootvetstvie vnutrennemu zakonodatelstvu $i$ meždunarodnym obâzatel'stvam Ukrainy $v$ oblasti zaŝity prav nacional'ny men'šinstv, w: Strategiâ nacional'noï konsolìdaciï v Ukraïnì: Pošuk modelì mižnacional'noï integracï̈, red. O.G. Svistunov, Užgorod 2000, s. 67-68.

13 Zob. O.N. Bikov, Konstitucijno-pravovij status..., s. 53-54.

14 Ukraïns'ke suspil'stvo. Monitoring socìal'nih zmìn, vip. 3 (17), Kiïv 2016, s. 466; Ukraïns'ke suspil'stvo. Monitoring social'nih zmin, vip. 4 (18), Kiïv 2017, s. 537. 
Ksenofobia na Ukrainie najczęściej przejawia się w postaci aktów wandalizmu wobec zabytków religii, historii i kultury mniejszości narodowych, ksenofobicznych graffiti i okrzyków w miejscach publicznych. Co pewien czas pojawiaja się mnie lub więcej zawoalowane ksenofobiczne publikacje w marginalnej prasie i w sieci internetowej. Trzeba też mieć na uwadze to, że akty ksenofobii moga być inicjowane przez zewnętrznego agresora w celu dyskredytacji Ukrainy.

Polityka etniczna i narodowa państwa jest $z$ jednej strony probierzem gotowości Ukrainy do integracji $z$ europejska przestrzenia polityczno-kulturalna i prawna, $z$ drugiej zaś może pełnić rolę praktycznego narzędzia zbliżenia się Ukrainy do Europy poprzez współpracę $z$ europejskimi rząami i organizacjami działajacymi na rzecz ochrony praw mniejszości narodowych. Wkrótce po uzyskaniu przez Ukrainę niepodległości we współpracy $z$ niektórymi innymi państwami powołano dwustronne komisje ds. mniejszości narodowych - ukraińsko-słowacką i ukraińsko-węgierską. Komisje te opracowują i uzgadniają wspólne działania w zakresie świadczenia pomocy prawnej dla przedstawicieli mniejszości narodowych, sprzyjania rozwojowi ich tożsamości, analizy realizacji wspólnych programów itp. ${ }^{15}$

Ogólny stan sfery etnopolitycznej Ukrainy pozwala na stwierdzenie, że pod kątem zasad prawnych, struktury organizacyjnej państwowego zarzadzania etnopolitycznego oraz atmosfery stosunków międzyetnicznych w społeczeństwie sfera ta zyskała cechy świadczące o jej europejskiej orientacji. Największe problemy istnieją w praktycznym zastosowaniu zarzadzania etnopolitycznego, aczkolwiek powodowane są one nie brakiem profesjonalizmu osób nią się zajmujących, a tym bardziej nie lekceważeniem europejskich zasad, lecz niedostatkiem zasobów spowodowanym permanentnym kryzysem gospodarki narodowej.

Z języka ukraińskiego przełożył Andrij Saweneć

${ }^{15}$ Zob. O.N. Bikov, Konstitucìjno-pravovij status..., s. 135-136. 